\title{
Dynamism and embeddedness: towards a lower road? British subsidiaries of American multinationals
}

\section{Ian Clark and Phil Almond}

\begin{abstract}
This article examines the effects of changes in the dynamics of the American national business system on industrial relations settlements in the UK subsidiaries of American multinational corporations (MNCs). While institutionalist analyses of country-oforigin and host-country effects must take account of changes in national business systems, such as the rise of the shareholder value ideology in the USA, empirical analysis reveals a pattern of pathway adjustment rather than radical change in employment relations at the UK subsidiary level. This suggests that although US MNCs are embedded within the American business system, their subsidiaries are not passive ciphers but autonomous sites through which influences must pass.
\end{abstract}

\section{INTRODUCTION}

Over the past three years, our reviews (Almond et al., 2003; Clark et al., 2002; MullerCamen et al., 2001) have explored several issues in the unfolding debate on multinationals and national business systems. First, we examined relationships between home and host country influences and the effects of these on industrial relations in multinational corporations (MNCs). Second, we explored the means by which industry-specific, that is sector pressures, are mediated by national business systems, in particular, embedded features of the industrial relations system. Third, we reviewed the extent to which the neo-liberal shareholder value ideology is becoming embedded within European business systems and the conflicts and challenges this may bring forth in national systems of industrial relations. This year, we consolidate these reviews by examining how contemporary business practice, associated business models and internal operating procedures within the American business system (ABS) may or may not influence and impact upon established patterns of industrial relations management in British subsidiaries of American MNCs. Equally, we seek to suggest how established settlements within firm-based employment systems may or may not combine with host-country effects to constrain such innovations.

$\square$ Ian Clark is Principal Lecturer and Philip Almond is Lecturer, Leicester Business School, De Montfort University. Correspondence should be addressed to Philip Almond, Department of HRM, Leicester Business School, De Montfort University, The Gateway, Leicester LE1 9BH, UK; email: palmond@dmu.ac.uk 
Evaluation of the tension between historically embedded features in the ABS and more dynamic contemporary features of the ABS and the effects of these on the management of industrial relations in British subsidiaries of American multinationals is important on four grounds. First, and most substantively, whilst US MNCs are embedded within the ABS and seek to transfer this influence through subsidiary operations in host countries, the ABS itself is very fluid and dynamic. Rhetorically at least, these characteristics permit American firms the scale and scope to change and amend business strategies and structures with great rapidity in response to contemporary market imperatives and technological influences. It is likely to be the case that the country-of-origin effect associated with US MNCs reflects a tension between established patterns of embeddedness and contemporary dynamism within the ABS. Working out the tension may, over time, change the relative significance of component elements within Americanness, including established patterns of industrial relations management. However, our empirical material may shed light on the tension between potential innovations associated with contemporary country-of-origin effects flowing from the ABS in relation to established country-of-origin effects in the management of industrial relations. This point is significant to academics, policy makers and practitioners alike. Academically, it may demonstrate how US MNCs accommodate contemporary influences and pressures that emanate within the ABS and transfer these to subsidiary operations and how they affect established patterns of industrial relations or how they are constrained by them. Similarly for policy makers and practitioners, pressures for and innovations within subsidiaries of US MNCs may become measures of competitive best practice in indigenous firms. ${ }^{1}$ Equally, established patterns of regulation within subsidiary operations together with host country regulation may constrain pressures for and innovations in management practice associated with contemporary country-of-origin effects. For example, legal regulation such as European Works Councils in subsidiary operations may forestall rapid changes in corporate strategy, whereas information and consultative committees may prevent the use of innovatory strategies for redundancies, such as 'culling' (see below) from finding acceptance within firm-level employment systems.

Second and related, the evident country-of-origin effect associated with subsidiaries of US MNCs suggests that these MNCs act as deviant innovators in the management of industrial relations, challenging established patterns of regulation in host business systems such as collective bargaining in the UK. However, given the domestically inspired changes to British industrial relations over the past 20 years non-unionism can no longer be referred to as an innovation, leading us to suggest that innovations are more likely to originate from developments in corporate governance, such as the emergence of shareholder value (see O'Sullivan, 2000) but may nevertheless impact upon industrial relations.

Third, foreign direct investment (FDI) by US MNCs accounted for at least 44 per cent and at most 68 per cent of annual FDI in the UK between 1965 and 1998. These levels are far greater than figures for FDI from other business systems (Dunning, 1998: 291) with FDI by US MNCs in the UK accounting for 14 per cent of all US FDI in 2002 (UNCTAD, 2002). So the sheer size of American FDI in the UK is likely to have a measurable impact on industrial relations management within and beyond subsidiaries of US MNCs.

\footnotetext{
${ }^{1}$ We have previously noted this with respect to non-unionism in Ireland (Almond et al., 2003).
} 
A fourth reason why the tension-bound relationship between established patterns of embeddedness and contemporary dynamics within the ABS is significant relates to the potential impact of more determined shareholder value and financial shorttermism on established patterns of industrial relations management within our case study firms. As we reported last year, shareholder value and financial short-termism may reinforce the well established preference for non-unionism and union avoidance in US MNCs (Almond et al., 2003: 433). More significantly than this, these pressures may challenge employer commitment to long-term, secure employment and employee voice mechanisms within welfare capitalist firms too, pushing all varieties of Americanness in industrial relations management in the direction of lower road employers. This, too, is significant to policy and practitioner debate. The success of innovatory business practices - labour flexibility and empowerment, the choice to work long hours, competitive performance management and associated 'culling' -was first brought to prominence by British subsidiaries of US MNCs. Several of these practices have the potential to lean towards a lower road and politicians and employer groups such as the British Chambers of Commerce, the Confederation of British Industry, the Chartered Institute of Personnel and Development, and the Institute of Directors, cite measures to regulate these practices to illustrate the 'burden of red tape' and anticompetitive impact of regulation and employment rights associated with the emergent European model of employment. For example, the Institute of Directors estimated that the working time directive cost British business $£ 2.3$ billion in 2003 (Financial Times, 2003a). Similarly, in respect of Information and Consultative Committees, Ministers have continually stressed the consultative nature of these and their lack of impact on British flexibility and the managerial prerogative (Financial Times, 2003b), whereas the Conservative opposition made the anticompetitive nature of European regulation a central feature of their European election campaign during 2004. The success of these arguments and supporting evidence is likely to further legitimise the already dilettante approach of the Blair government to European employment directives (see also Barnard et al., 2003).

The diffusion of greater pressures for short-termism is common to both the American and the British business system but the argument we develop suggests that whilst both systems are examples of liberal market economies (Hall and Soskice, 2000), there are considerable differences between the two. For example, whilst within both systems, financial measures of competitiveness such as share price and shareholder value are vital to create and sustain job creation and labour flexibility in the ABS functional and numerical flexibility combined with a series of organisational capabilities. In contrast to this, in the UK, competitiveness and flexibility are more generally defined and relate to openness of the economy, the lightness of regulation therein and the positive effects of these on job creation. The term 'parallel tendencies' captures the dynamic similarities between the two business systems, but in addition, establishes the embedded differences between them. Further to this, business systems more firmly located in the EU stakeholder model where measures of competitiveness include not only financial imperatives but longer term measures such as functional flexibility, innovation and a longer term financial horizon are encountering the effects of these parallel tendencies. However, operating as they do from a state-centric as opposed to a state-abstentionist tradition, the effects of emergent short-termism are mediated and managed by the stakeholders in a more consensual manner than in the UK or the US (see Barnard et al., 2003: 475). We will examine this issue in more depth in next year's review when we compare and contrast the arguments and find-

(C) Blackwell Publishing Ltd. 2004. 
ings reported on here with the findings of our colleagues in Germany, Spain and Ireland.

Accordingly, to flesh out the discussion of contemporary pressures within the ABS and the potential effects of these within and beyond British subsidiaries of US MNCs, our review proceeds through three parts. To establish a framework that examines policy transfer within US MNCs and British subsidiaries and the potential for tensions within this process, part one briefly outlines embedded features of the ABS and contemporary influences in business practice. Identifying the dimensions of embeddedness and more contemporary and dynamic business pressures stimulate hypothesised links to practice - country-of-origin effects, firm-specific effects and host-business system effects - in subsidiaries with different styles of decision-making and industrial relations management. Part two reports on empirical findings from a four-year study of industrial relations in British subsidiaries of US MNCs to reveal the effects of contemporary influences on the ABS and how these manifest themselves in subsidiary operations. Finally, part three places our argument and material on British subsidiaries of US MNCs within contemporary issues of debate on British industrial relations and offers some tentative conclusions.

\section{THE AMERICANNESS OF BRITISH SUBSIDIARIES OF US MNCs}

A key theme in research on multinational firms centres on how the behaviour of MNCs and the management of their subsidiary operations contribute to change and evolution in host business systems (Ferner, 1997). Our specific focus is the impact of subsidiaries of US MNCs in the British business system and the institutions of its industrial relations system; for example, collective bargaining. The literature, in particular Flanders (1964), Dunning (1998) ${ }^{2}$ and for a comprehensive review Edwards and Ferner (2002), suggest that US MNCs have, over the postwar period, acted as innovators in industrial relations management with many of these innovations flowing from business models and corporate structures established in and embedded within the ABS but alien to the British business system. For example, the diffusion of multidivisional structures for corporate organisation preceded and stimulated the movement to plant-level collective bargaining in and then beyond British subsidiaries of US MNCs (see Kipping, 1998). The impact of shareholder value and more determined pressures for short-termism is, as we noted last year, an innovation that may have an effect on industrial relations management in European business systems (Almond et al., 2003).

To assess this nationality and efficiency effect, we briefly detail what is distinctively American about the management of US MNCs. This is followed by a discussion of how the Americanness of US MNCs has sustained a variety of approaches to industrial relations management in their subsidiaries. We then suggest how contemporary imperatives within the ABS illustrate both the dynamism of the system and the impact of these imperatives on established approaches to industrial relations management in British subsidiaries. In summary, we identify shareholder value as a contemporary dynamic within the ABS that one would expect US MNCs to accommodate at

\footnotetext{
${ }^{2}$ It is important to point out that Dunning was first published in 1958, and therefore the main bulk of his empirical material and theoretical arguments relate to the mid-1950s. The 1998 edition does, however, include a chapter that contrasts his findings from the 1950s with the 1990s; the chapter further develops and compares and contrasts theoretical arguments between the two periods.
} 
corporate and subsidiary level relatively quickly resulting in an identifiable impact on patterns of decision-making.

\section{'Americanness': the distinctive qualities of US MNCs and their British subsidiaries}

The ABS is a distinctive model of economic organisation where market relationships represent the primary mechanism of coordination. Therein, atomistic firms engage with one another through arm's-length contractual relations. Historically, this model underpinned the growth and diffusion of large firms serving mass standardised consumer markets, wherein the market imperatives of growth and survival stimulated the development of centralised management control systems in production and work organisation, planning and budgetary control and personnel management. Summarised as a series of 'organizational capabilities' (Chandler, 1990), these formalised organisational bureaucracies saw firms develop further centralised controls over the management of labour including systematic management tools for job analysis, work study and the detailed division of labour in mass production systems that combined with the use of machinery and interchangeable parts (see Braverman, 1974; Edwards, 1979). The fusion of management control systems and dedicated machinery reduced throughput times and unit labour costs to allow large firms to increase market share by out-competing more specialised small-scale producers on price, delivery, replacement and repair. In summary, interaction between and within firms and their employees, as well as labour, financial and product markets are contractually based with very few legal or regulatory constraints on the conduct of these market relationships imposed by the American state (Ferner et al., 2004).

These organisational capabilities provide an enduring legacy that shaped later developments and innovations, particularly when American firms set up operations overseas. In other words, US MNCs are embedded within the institutional structure of the ABS and transfer aspects of this 'Americanness' to their subsidiary operations. For British subsidiaries, this process of transfer is all the more likely given the dominant position of US MNCs as inward investors in the UK.

\section{Varieties of Americanness: industrial relations management}

The organisational capabilities of American firms maintained by contractual and market relations, have historically operated in an individualistic ethos that promotes a strong anti-union mentality among American employers. However, the ABS has sustained a variety of patterns of industrial relations within unionised 'New Deal' employers and non-union employers that range from sophisticated 'welfare capitalist' firms which offer employees high commitment management and secure jobs to 'lowroad' exploiters of cheap labour. Welfare capitalist employers represent a sophisticated variety of non-unionism based on encouraging a strong mutual commitment between the firm and the employee characterised by a philosophical opposition to unionism (see Foulkes, 1980) and a belief that the firm, rather than the state or trade unions should provide for the security of workers. Hence, to substitute for trade unions, welfare capitalist firms introduce innovative personnel management policies in areas such as pensions, health care systems and unemployment insurance. Equally, they pioneered individual performance-related pay, profit-sharing and teamworking (Jacoby, 1997). They built employees' psychological commitment by promoting a strong explicit and inclusive corporate culture and employed social science techniques

(C) Blackwell Publishing Ltd. 2004. 
such as employee attitude surveys to keep in touch with employee opinion. However, where necessary they are prepared to 'play it tough' to quash attempts at union organisation (Jacoby, 1997). In contrast, New Deal employers concede union recognition and bargain in 'good faith' with trade unions over legally enforceable contracts and highly codified collective agreements - 'job control unionism'- that set detailed grading structures and procedures for grievance and discipline. In many respects, both varieties rested for success on structural factors such as stable product markets and the absence of marked business cycles. In recent years, the welfare capitalist model has been weakened by accelerating technological developments and intense international competition and both welfare capitalist firms and New Deal employers have faced crises that have threatened firm-level industrial relations settlements, possibly blurring the distinction between de-unionising New Deal employers and the nonunion sector. Such a development may push more employers in the direction of lowroad non-unionism where survival in highly competitive markets combines with high labour intensity and low skills and poor access to training (see Katz and Darbishire, 2000) However, the legacy of welfare capitalism and the New Deal remains in firmlevel employment systems. Here, a tradition of internal labour markets for core employees and in the role or vision of founding families may combine with hostcountry effects to sustain firm-specific employment systems. It is the embeddedness of these systems that may constrain the impact of contemporary business strategies which appear at first sight to threaten welfare capitalist or New Deal settlements.

\section{Contemporary imperatives in the ABS and British subsidiaries of US MNCs}

A dominant feature of the ABS that distinguishes Americanness from other business systems is the significance of centralised operations and organisational capabilities. These create a pattern of sustained competitive advantage that has enabled large American firms to out-compete smaller firms in the domestic market and as multinationals out-compete smaller firms in host economies. Witness, for example, the penetration of consolidation within and exit from motor manufacturing in the UK during the 20th century through a combination of organisational capabilities in production and aggressive merger and acquisition activity. The latter is indicative of a capability to sustain capital investment and productivity growth via market penetration that flows from embedded patterns of organisational capability and an emergent pursuit of shareholder value in the market. This point is important as it illustrates both the real and the symbolic nature of dominance. Embedded patterns of work organisation do create a distinctive competitive advantage but in addition 'dominance' is likely to be given meaning by the rhetorical and symbolic diffusion of imperatives and pressures in the ABS to subsidiary operations and indigenous firms in host economies. So, methods of organising production-volume standardised production - and its regulation become dominant if they invite emulation in other economies, first, in indigenous firms - the process of Americanisation (see Clark, 1999; Djelic, 1998; Zeitlin and Herrigel, 2002) and then, in subsidiaries of US MNCs - the emergence of Americanness, with the latter acting as a further spur to indigenous firms in host economies on the grounds of best practice and efficiency (see Dunning, 1998).

Despite the embeddedness of its organisational capabilities, the ABS is also distinctive in that the pattern of contractual and market relations - its market logic - facilitates rapid shifts in the form and meaning of its dominance For example, O'Sullivan (2000) argues that the movement from a 'retain and reinvest' managerialist mode of 
corporate governance to one that is dominated by a 'downsize and distribute' shareholder value model of corporate governance is significant because of its symbolism, and not because of its substance. This is the case because the shareholder value model has no theory of the firm or firm-specific assets, such as its employment system. It is clear that both of these are necessary for employers to generate profits, the distribution of which is the focus of shareholder value approaches. In the contemporary period developments in the financial system such as the growth of institutional investors, the influence of financial analysts, an aggressive market for corporate control (merger and acquisitions) and the pursuit of shareholder value have created a renewed emphasis on financial returns. This may put pressure on or break industrial relations settlements - internal constraints - within welfare capitalist or New Deal firms pushing each towards a lower road. This pressure may be manifested in the re-defining of centre-subsidiary relations in terms of subsidiary performance and autonomy or in broader approaches to industrial relations. A key point that we tease out in this respect is the degree to which such pressures are rhetorical and sustained but symbolic in terms of corporate discourse and catch-all as contemporary drivers of business strategy within and beyond British subsidiaries. The previous point is significant because O'Sullivan (2000) establishes that the theory of shareholder value, being essentially concerned with claims over profit, has no productive dimension, an absence that actually encourages stability in patterns of firm-specific settlements such as industrial relations.

\section{EMPIRICAL FINDINGS ON INDUSTRIAL RELATIONS IN BRITISH SUBSIDIARIES OF US MNCs}

The findings presented here are based on data from the British component of a study of industrial relations management in US MNCs across four European countriesBritain, Germany, Ireland and Spain. The aim of the research was to identify the influence of the US business system on the management of industrial relations in US MNCs and to evaluate whether 'Americanness' was manifested in different ways in different host environments. In order to establish linkages and understand processes, a qualitative method was adopted, based on eight in-depth case studies. The principal case studies are indicated in the table below. For reasons of confidentiality, pseudonyms are used throughout.

\section{The case study companies}

Most of these companies are major players in their respective industries, therefore our sample is representative of larger MNCs, the majority of which are long-established in the UK - with the exception of Logistico, which recently entered the UK market, along with other European markets, via acquisition of brownfield sites - rather than establishing new greenfield sites (Table 1).

\section{Established approaches to industrial relations in the UK and US}

The established approaches to collective industrial relations in these companies are presented in Table 2. As can be seen, in the US, a number of the firms (CPGco, ITco, Household) fit the welfare capitalist archetype. In a further two (EngServs, Pharma- 
Table 1: The case study companies

\begin{tabular}{|c|c|c|c|c|}
\hline Codename & Sector & $\begin{array}{l}\text { Global } \\
\text { employment } \\
(000 \mathrm{~s})\end{array}$ & $\begin{array}{c}\text { UK } \\
\text { employment } \\
(000 \mathrm{~s})\end{array}$ & $\begin{array}{l}\text { Established } \\
\text { in the } \\
\text { UK since }\end{array}$ \\
\hline CPGco & $\begin{array}{l}\text { Manufacturing: } \\
\text { consumer and } \\
\text { professional products }\end{array}$ & 75 & 3 & $1880 \mathrm{~s}$ \\
\hline Engco1 & $\begin{array}{l}\text { Manufacturing: capital } \\
\text { engineering equipment }\end{array}$ & 69 & 2 & $1950 \mathrm{~s}$ \\
\hline Engco2 & $\begin{array}{l}\text { Manufacturing: capital } \\
\text { engineering equipment }\end{array}$ & 28 & 5 & $1970 \mathrm{~s}$ \\
\hline EngServs & $\begin{array}{l}\text { Process plant } \\
\text { construction services }\end{array}$ & 11 & 2 & $1920 \mathrm{~s}$ \\
\hline Household & $\begin{array}{l}\text { Manufacturing: } \\
\text { consumer household } \\
\text { products }\end{array}$ & 10 & 0.7 & $1910 \mathrm{~s}$ \\
\hline ITco & IT services & 365 & 20 & $1950 \mathrm{~s}$ \\
\hline Logistico & Logistics services & 360 & 4 & $1990 \mathrm{~s}$ \\
\hline Pharmachem & $\begin{array}{l}\text { Manufacturing: } \\
\text { chemicals and } \\
\text { pharmaceuticals }\end{array}$ & 13.7 & 0.15 & $1910 \mathrm{~s}$ \\
\hline
\end{tabular}

chem), there has been some union influence within generally non-collective industrial relation strategies, while Engcol and Logistico can be considered as fitting the New Deal archetype. Finally, Engco2 is a more complex case; historically the firm has championed a relatively tame form of trade unionism, shorn of links to the wider labour movement. This represents a variant of welfare capitalism, because it clearly had the aim of avoiding the national unions. It should be noted that none of the firms reported on here have historically taken an explicitly low-road approach to industrial relations in their domestic operations.

\section{Collective industrial relations in British subsidiaries}

Of the three welfare capitalist firms, all of them have historically resisted unionisation in the UK, although CPGco eventually conceded union recognition following several years of struggle in the 1960s and 1970s. In the two partially unionised companies, the same pattern of opposition to union influence, where this is feasible, is essentially replicated. The one New Deal firm that is well established in the UK (Engco1) has historically acquiesced with British pluralism, as has Engco2. Logistico's entry into Britain is too recent to talk of an established approach. Where UK operations were only partly unionised or non-union, this reflected a non-union ethos transmitted by the centre to world-wide operations, generally accompanied by sophisticated paternalist measures that attempted to reduce the probability of union organisation. The example of ITco is instructive here. During the 1970s, unions were pressing to recruit members and succeeded in using the quasi-statutory union recognition procedure in place at the time to force the issue. British managers campaigned strongly against 


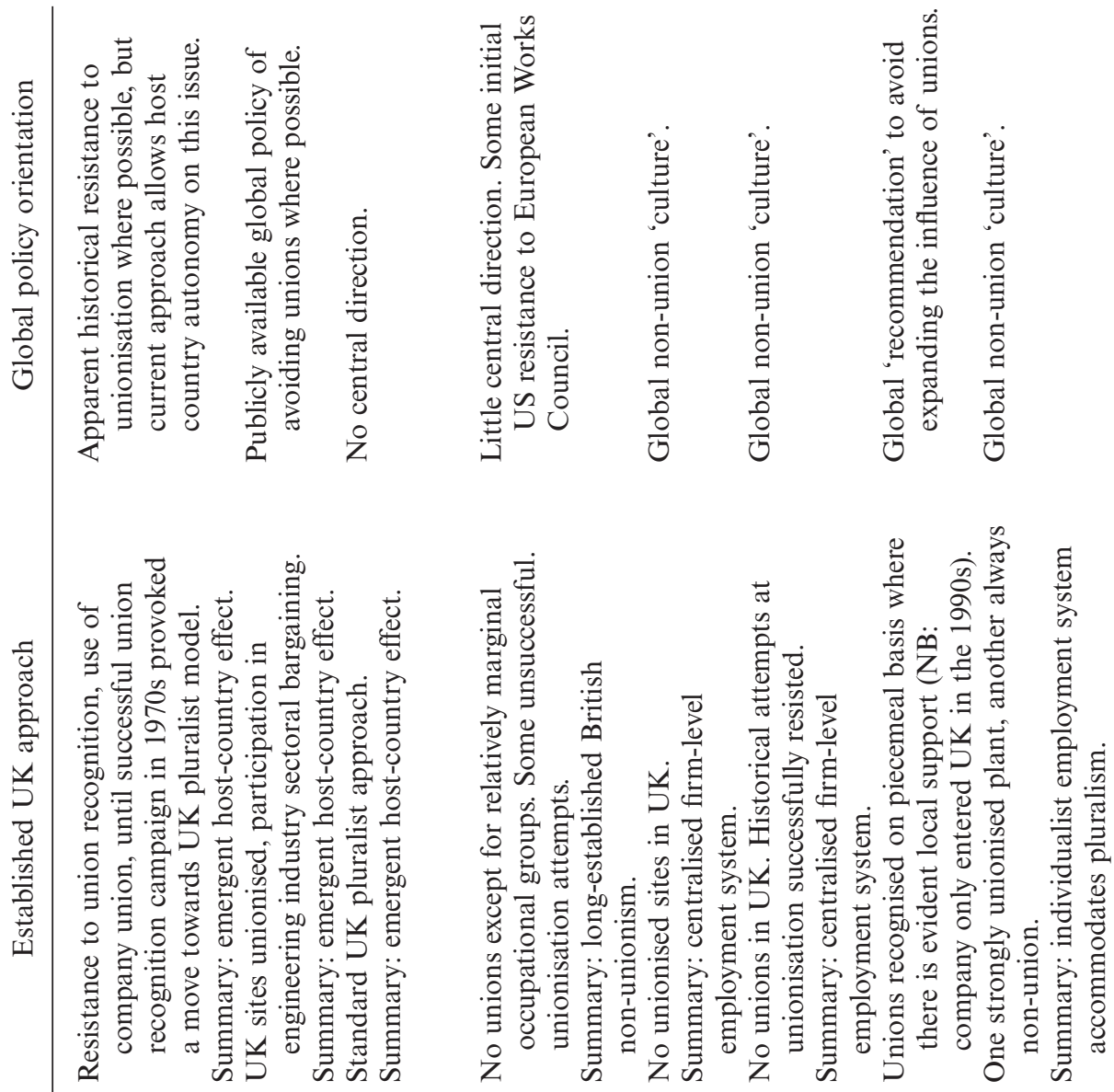
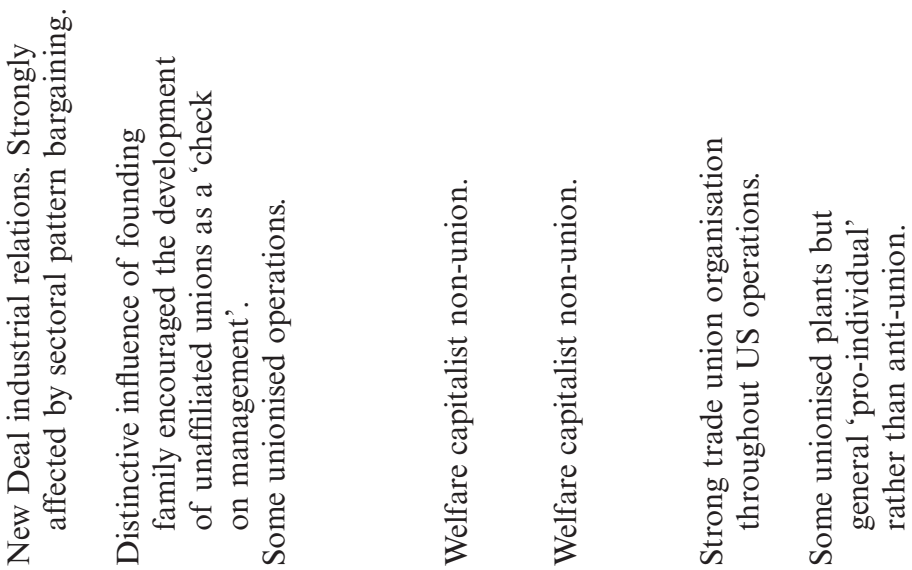

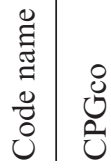

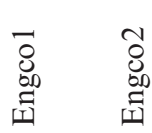

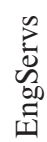

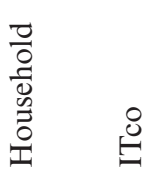

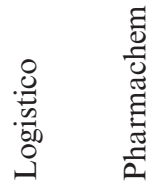


recognition, stressing the company's paternalist policies; one of those involved in the managerial campaign reported that they had told the workforce that 'you're joining ITco; ITco will look after you from cradle to grave'. These tactics worked, in that there was a large majority against union recognition. A senior manager who had been involved in the company's campaign described the 'halo effect' that they had enjoyed for some time following this victory in the eyes of corporate HQ:

So we were heroes to the States. Here was the system, this great system which was the creation of [the founding family], this was the system being tested. So we had letters of congratulation, 'wonderful achievement', 'shows the system works'. It was a vindication that had never been attained before, because there had been no vote on the ITco system [Retired UK HR manager, ITco].

Although there appears to be a reasonable degree of correlation here between US and UK approaches, what is more interesting, is the extent to which policy has changed in recent years, and the extent to which this can be ascribed to a strategy emanating from the country of origin, rather than to secular developments in the UK. Particularly, given the apparent constraints of the New Deal industrial relations system and the difficulties involved in maintaining the more paternalist policies involved in the welfare capitalist model, how has the nature of Americanness in industrial relations changed?

\section{Challenges to firm-based employment systems?}

Most of the companies have been subjected to a variety of pressures with the potential to undermine their firm-based employment systems in the US and elsewhere, be they welfare capitalist or New Deal.

In a number of the cases, changes in product markets were the most obvious factor provoking change. CPGco and ITco, in particular, lost stable monopolistic positions as the nature of the product market altered substantially. In other cases, particularly the engineering companies, pressures primarily arose not from changes in the nature of the product, but from a marked internationalisation of competition, particularly from Japanese competitors. In the case of Engco1, this new competition for the US domestic market was a strong factor in the firm's rejection of New Deal pattern bargaining, as it argued that other firms within the sector were not facing the same degree of pressure from international competition due to import restrictions in, for example, the automobiles sector.

The exacerbation of the shareholder value ideology as a modus operandi for public quoted firms in the USA (O'Sullivan, 2000) was also a factor in most of the firms. Although it is hard to disentangle this from the market pressures cited above, in both CPGco and ITco 'outsiders', with reputations of managing for shareholder value, were appointed as CEOs during the 1990s. The same occurred in Engco2, in this case following a failed hostile takeover bid. In all of these cases, subsidiary managers were well versed in pressures to produce quarterly results.

To these pressures may be added more specific issues and developments in industrial relations, particularly the reduction of trade union strength in the USA where the decline both of New Deal models and of welfare capitalist paternalism are part of the response to pressures external to industrial relations listed above. Equally, decline is greatly facilitated by the difficulties unions face in organising in the US, many of which relate to the decline in the manufacturing workforce; the increased international mobility of capital; and the collapse of political support for the New Deal model. 
Unsurprisingly, the main pillar of firm-level employment systems that has failed to survive the developments above has been policies on employment security, with significant downsizing and restructuring being a widespread phenomenon. This development has had particularly strong effects on the two most stereotypical welfare capitalist firms, CPGco and ITco, which had, prior to the late 1980s, avoided redundancies. Equally, in unionised companies such as Engco1, increased product market competition, particularly in this case, the challenge from Japan, has been a significant driver behind the firm's rejection of the New Deal model in the US.

Yet, if the binary split between welfare capitalism and New Deal-ism is no longer an appropriate characterisation of the employment policies of those large American firms that eschew a simple 'low-road' model, it is less clear what changes and innovations have either impacted on or been accommodated by these approaches. As our interest here is primarily in employment relations in the UK operations, we need to examine the extent to which these firms exhibit some form of 'contemporary Americanness' at their British subsidiaries.

\section{Established employment systems in British subsidiaries}

One complicating factor here is the degree of centralisation of policy on industrial relations and other aspects of human resources (HR). Comparing, for instance, CPGco and ITco once again, their objective conditions are in some ways fairly similar. Both are traditional welfare capitalist firms, both have seen the erosion of product market monopoly, and subsidiary managers in both have strongly emphasised the pressures brought about by the firms' commitment to shareholder value. Yet, whereas ITco's strong historical non-union ethos is transferred to international operations wherever possible (similar policies apply, albeit less rigidly in Household and Pharmachem), CPGco seems to be primarily interested in preventing unionisation in the US. There is no central direction of subsidiary union recognition policy, as managers at both European and corporate headquarters underline that the parent company does not 'understand' collective issues. Similarly, Engco2, which is not specifically antiunion in the US but prefers to deal with 'independent' unions, gives no global direction on collective recognition issues.

Global anti-union policies exist outside the welfare capitalist group. Engco1, perhaps unsurprisingly in the light of its battles with trade unions in the US, has a clause in its publicly available world-wide code of conduct of trying to create the right environment where employees do not feel the need for 'third parties'. In contrast to this, Logistico, where the union in the US is currently too strong to be challenged directly, has a 'recommendation' to minimise the potential for organisation of unions. If a European subsidiary felt it had specific reasons to break with this recommendation, it would have to present a case to the European HR Director. EngServs, the most decentralised of our firms on all other aspects of HR and business coordination, has no formal international policy on union recognition, but UK managers reported resistance from central managers to the establishment of a European Works Council, on the grounds that this could be 'a bridge to the unions'.

In terms of management-union relations, the overall picture is one of relative stability (see Table 3). In spite of the economic and financial challenges of the last two decades and the political window of opportunity that Thatcherism presented for attempts to challenge unionised settlements, moves away from collective models have predominantly been at the margins; for example, unions without strong workforce support were derecognised at Engcol and Pharmachem. A collectivised pattern of

(C) Blackwell Publishing Ltd. 2004. 
Dynamism and embeddedness

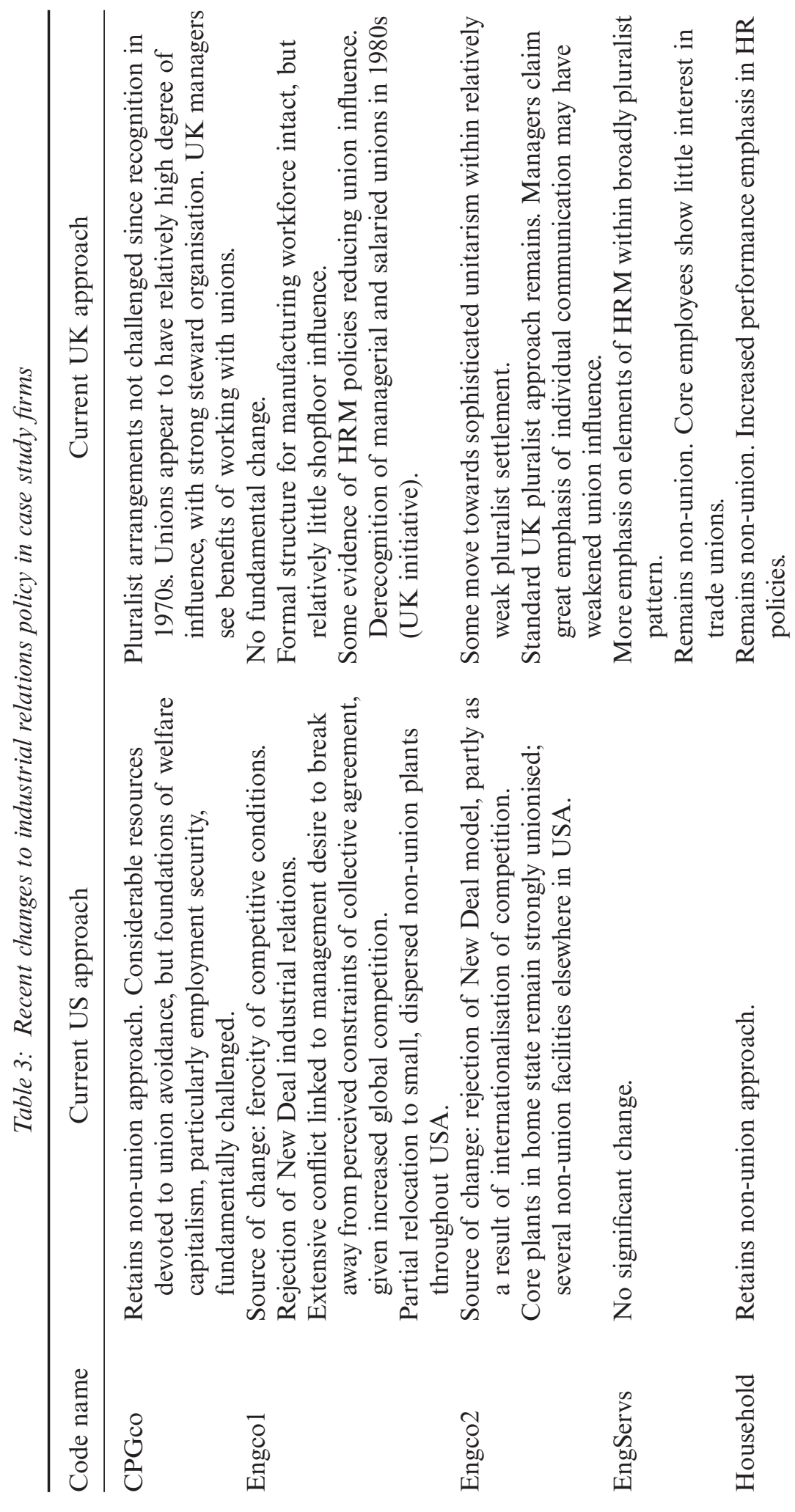

(C) Blackwell Publishing Ltd. 2004. 


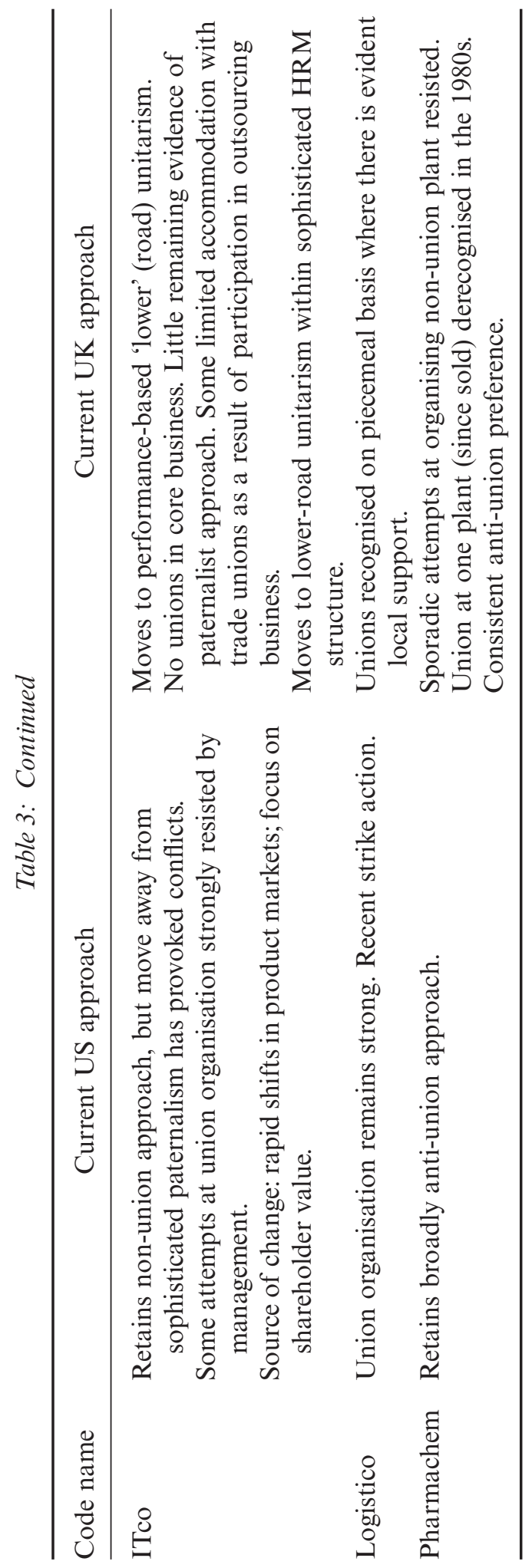


industrial relations is most prevalent at CPGco, in spite of its non-union approach in the US and the prolonged fight against recognition challenges in the UK; unions now appear well organised, and there is widespread consultation and UK managers show no interest in changing the status quo. In some of the unionised companies, as in the British economy more widely, there are indications that the union role has been marginalised due to the introduction of more individualist policies in the areas of teamworking and employee involvement, but there is little support for the idea that this was the motive behind the introduction of such policies. In spite of its derecognition of unions representing salaried groups, Engcol appears to have contradicted formal global policy in not challenging the shopfloor union, and seems content to follow the standard British pattern within the engineering sector. Finally, ITco has retained a strong and successful opposition to trade unions within its core businesses, but its recent entry into the IT outsourcing market has resulted in the need to accommodate trade unions in some transfers of undertakings (protection of employment) and here British managers reported on the advantages of dealing with unions. While this is not a dramatic development in terms of ITco UK generally, interviews with retired managers suggest that the very existence of unions in the firms for whom ITco takes over the IT function would, until recent product market difficulties, have been enough to prevent investment in such markets. In this respect, we can conclude that tighter competitive conditions in the UK prevent strategic choice and established preferences in approaches to industrial relations from constraining investment activity.

\section{Other innovatory developments and changes to employment relations settlements at British subsidiaries?}

Naturally, a discussion on change in industrial relations among US MNCs needs to go beyond the totemic issue of collective recognition and consider other areas of HR. In examining the nature of contemporary 'Americanness', therefore, we now turn to the substantive issues of pay and performance management, and work organisation, as highlighted by Dunning (1998).

On the management of pay, the majority of the firms studied have a worldwide system of grades applying to the workforce as a whole. However, tensions remain between pressures for uniformity and host country autonomy. Although definitions of job grades tend to be centralised and 'global' in nature, some autonomy remains in wage setting. This is greater for non-managerial workers, and where there is collective bargaining in the British subsidiary.

Reflecting a more general trend, both in the USA (Dessler, 2003) and elsewhere, there has been a move away from a multiplicity of narrow pay grades to 'broadbanding' (CPGco, Engco1, EngServs, Household, ITco). However, with the exception of ITco, this has not been accompanied by any measures such as competence-based pay designed to allow some visible form of salary progression within flatter organisational structures. Thus, for shopfloor workers in several of these firms, there is little chance of salary progression other than through promotion to supervisory or management roles. Here, then, specific innovation in British subsidiaries is limited to attempts to simplify grading structures worldwide.

The majority of the firms here are perhaps more innovative with regard to reward for individual performance. Unsurprisingly, all the case study firms had a form of individual performance-related pay, with some (ITco, Household, EngServs) using it throughout the hierarchy rather than merely for managers. In nearly all cases, the 
nature of individual performance management was strongly led by global management rather than devolved to the UK subsidiary. Significantly, a number of companies (CPGco, Engco2, ITco) used performance against competencies, corporate values or personal qualities and characteristics (e.g. leadership, valuing diversity, etc.) as modifiers of individual merit pay. In this way, the firms attempted to use remuneration to reinforce and sometimes to change corporate values.

One prominent initiative, reflected in increased 'marketisation' in the employment relationship, was the use in several cases of 'forced' distributions in performance management, such that a certain percentage of workers had to be placed in the highest and lowest performing categories. The use of forced distributions by US MNCs becomes particularly significant when the data gathered are not only used to determine pay increases, but also affect the job security of the individual. The dismissal of those individuals with poor performance rankings may occur in two ways. The stricter means is the General Electric model (Lawler, 2002), where the 10 per cent with the poorest results are liable to be dismissed, or 'culled'. This model was introduced explicitly in Engco2 as part of a drive to make the organisation more focused on performance, although there was significant managerial resistance to the use of this policy in the UK. Elsewhere, while there is no explicit policy of 'culling' the lowest performers in a forced distribution, it is clear that those in the bottom groups are the most likely candidates for redundancy in the event of downsizing (this was most clearly the case in ITco). This model, although legally questionable in a European context, depending as it does on the American concept of 'employment at will', clearly represents a move away from the 'last in first out' model which has historically been a feature of large firms with strong internal labour markets as part of firm-specific settlements. The definition of 'fairness' in who should be made redundant has clearly been altered, marking a further move away from the assumptions of welfare capitalism or the New Deal model within which the subsidiaries remain encased.

On work organisation, despite the rhetoric of teamworking, there was little sign that the subsidiaries of US MNCs were more innovative than their UK counterparts in the same sector. Indeed, rather than a 'new' form of country-of-origin effect emerging from the challenges of recent years in standard manufacturing settings such as CPGco, Engco1 and Engco2, the legacy of Taylorism remained strongly apparent. Tasks tended to be fragmented and executed under significant management direction. There was a significant degree of subsidiary autonomy over the pace and detail of teamworking programmes, but underlying controls over product design and production technology continued to place limits on the extent of team autonomy. Relatedly, there were some signs of moves towards more sophisticated but sector-specific strategies of work organisation in high-skill sectors such as engineering services where EngServs operates. However, our fieldwork suggested that this resulted from sector and nationality effects, not central direction from the corporate headquarters (see Colling and Clark, 2002).

In summary it is clear that contemporary pressures from the ABS are transmitted through to British subsidiaries. However, these pressures display a relative lack of effect on collective industrial relations where it is present suggesting that centralised opposition to trade unions is, in some of the cases, an already established country-oforigin effect. There is some evidence of increased centralisation possibly resulting from greater pressures towards shareholder value, for example, reduced employment security, increased marketisation of pay and performance pushing the overall management of subsidiaries towards a contractual approach and further away from one based on

(C) Blackwell Publishing Ltd. 2004. 
status; but our cases suggest that this movement can be accommodated within existing approaches to industrial relations.

\section{INNOVATION, INTERNATIONALISATION AND BRITISH INDUSTRIAL RELATIONS}

A fundamental premise of our research on British subsidiaries of US MNCs is that US MNCs are embedded within the assumptions, practices and contemporary dynamics of the ABS. Following on from this, US MNCs are likely to transfer aspects of 'Americanness' to their operations abroad where within the global and increasingly internationalised economic system, the USA occupies a dominant position, reinforced by its military and political strength since 1945 . This dominance is likely to encourage other national business systems to 'import' American models. To evaluate the dynamics and contradictions of this process for British industrial relations, we engage with two wider issues of debate to further examine our argument; namely the 'productivity gap' and the relationship between short-termism, shareholder value and organisational capabilities. Our reasoning for making this argument is twofold; first, to place our findings on British subsidiaries of US MNCs more firmly in the context of the British business system; and second, to demonstrate that further research on the details of the transfer process of Americanness within US MNCs and indigenous firms is necessary.

\section{The productivity gap}

What is now termed the 'productivity gap' was first identified by Dunning in the 1950s $(1985 ; 1996 ; 1998)$. Concerned with the recovery of the British economy from the Second World War and its longer term performance, Dunning argued that the transfer of American managerial know-how would be beneficial to the British economy if the distinctive characteristics of American management style and strategies could be transferred to subsidiaries of US MNCs and indigenous firms. Dunning (1998) further hypothesised that if this succeeded in narrowing the productivity gap between the two business systems, the transfer process would demonstrate that much of this superior performance rested on the adoption of a series of organisational capabilities developed by American management. Dunning demonstrated that American subsidiaries tended to have higher levels of productivity and more orderly patterns of personnel management and industrial relations than British firms in the same sector. Dunning's (1998) argument is significant to contemporary debates because his findings reveal that component elements within what is now termed human resources management (HRM) - incentive schemes, profit sharing, employee stock option plans (ESOPs), group work (teamwork), group and individual lump-sum bonuses (performancerelated pay) and 'worker assessments' (appraisals) — were well developed in British subsidiaries in the 1950s. This suggests that the train of innovation associated with US MNCs has a long pedigree but takes some time to spread to indigenous firms and the long train of diffusion indicates the presence of host country constraints within the British industrial relations system during the postwar period. Efforts to remove or heavily regulate these constraints that were introduced by the Thatcher governments from 1979 not only failed to encourage the diffusion of more developmental HR policies in indigenous firms but resulted in the dominance of American firms in 
many sectors. More significantly than this, the UK's productivity differential with the United States remains substantial at around 38 per cent (Financial Times, 2004; Nolan and Slater, 2003: 76). So British subsidiaries of US MNCs are industrial relations innovators and these innovations do connect with embedded patterns of organisational capabilities that constitute a key source of sustained competitive advantage over British firms. However, the diffusion of HR policies and contemporary innovations such as downsizing and shareholder value in indigenous firms may not necessarily combine with organisational capabilities but the tradition of 'unscientific management' preferred by British employers (Clark, 1999; 2001; Hyman, 2003). Thus whilst Dunning's arguments about the diffusion of US managerial strategies and style appear at first sight convincing, the diffusion of these within British firms is unlikely to raise efficiency levels to an American standard. This conclusion, although partly speculative, raises a further qualification to Dunning's hypothesis; it is more likely that the tradition of British management is a more significant host country constraint than organised labour to the successful diffusion of American management techniques within indigenous firms. For example, commenting on the new research agenda of HRM and performance in British firms, Nolan and O'Donnell (2003: 505) argue that this is likely as HRM appears embedded within established management systems in British-based firms rather than making them more American; that is, combine them with a series of organisational capabilities. More critically than this, it is important not to over-hypothesise about the adoption of sophisticated HRM policies in the ABS; for example, Kochan and Osterman (1994) suggest that this is less likely to be the case in the absence of reform in the ABS. It follows from these arguments that the embedded organisational capabilities (production management, work organisation and centralised control of personnel and industrial relations) associated with managerial capitalism are more likely to secure American competitive advantage than HRM, sophisticated or not. Our research findings on US subsidiaries are unable to offer any definitive conclusion on this point because we lack comparative data on British firms in the same sectors and this research gap points to the value of research that matches pairs of British and American firms in the same sector.

\section{Shareholder value and organisational capabilities}

Whilst O'Sullivan (2000) is often credited with pointing to the contemporary significance of shareholder value and the impact of this on how American firms make effective strategic choices that aim to maintain embedded sources of competitive advantage, these pressures are not necessarily new in the British business system. Borrowing from Thompson (2003), this points to the possibility of a theoretical discontinuity in the evaluation of short-termism and shareholder value in that shortterm pressures are already embedded within the British business system. Americanness suggests a pattern of innovation and change inspired by the transfer and then more widespread diffusion of business and work practices first introduced in American MNCs. More pertinently for our specific research findings on the question of innovation from the ABS, one of our key hypotheses laid out in the section 'The Americanness of British Subsidiaries of US MNCs' is that US MNCs are innovative both in the particular area of industrial relations and HR and business practices more generally, with the latter having significant implications for industrial relations. Whilst this argument appears convincing in respect of contemporary innovations such as the emergence of shareholder value and more determined short-termism, on closer exam- 
ination, the argument may be less convincing. By this we mean that firm-specific employment systems retain the legacies of welfare capitalism and New Deal approaches to industrial relations; in particular, this includes the legacy of more pluralist approaches to industrial relations, sometimes reluctantly, sometimes voluntarily introduced in British subsidiaries.

There is some evidence in our case study material to suggest that internal settlements within American subsidiaries, whether they are New Deal or welfare capitalist, have been put under pressure by proposals for more determined financial engineering. But as Table 3 illustrates in several cases, internal settlements have proved relatively resilient in tempering such pressures. This leads us to the conclusion that as an innovation, the emergence of shareholder value and more determined short-termism within British subsidiaries of US MNCs is only as significant as the existing pressures on indigenous firms embedded within the British business system.

\section{CONCLUSIONS}

A significant feature of the ABS is the organisational capability of American business which tends to have centralised systems of personnel management and industrial relations rolled out by high profile well-resourced HR functions such as those reported on in our case study firms. In MNCs, these departments seek to transfer aspects of this Americanness to overseas subsidiaries, which in turn act as innovators in host business systems for indigenous firms. However, our evidence suggests that the picture is necessarily more complicated than this for subsidiaries. This is the case because British subsidiaries, whilst they may reflect Americanness, become part of a wider firm-specific employment system that incorporates host-country effects such as collective bargaining in otherwise anti-union firms. Similarly, in respect of contemporary pressures transmitted from the ABS, firm-specific employment systems are in part sustained by the legacy of welfare capitalism or New Deal approaches to industrial relations. This leads us to the interim conclusion that host-country effects and the embeddedness of welfare capitalism and New Deal influences may act as constraints on the smooth transmission of contemporary business pressures from the ABS to British subsidiaries.

The arguments and evidence cited in the section 'Innovation, Internationalisation and British Industrial Relations' suggest that subsidiaries of US MNCs are innovators in the field of personnel and industrial relations, business models and business strategies more broadly defined. However, whilst the organisational constraints imposed on the managerial prerogative by British trade unions are now marginal, the legacy of unscientific management in British firms remains. As a result of this, personnel and industrial relations innovations in British firms first aired in subsidiaries of US MNCs are less likely to combine with a pattern of sustained competitive advantage that follows from embedded organisational capabilities in US MNCs. Perversely, our argument leads us to speculate that in some cases, the Americanness of British subsidiaries of US MNCs that incorporates organisational capabilities within wider but firmspecific employment systems are better equipped to protect employees from the consequences of contemporary business practices than those found in British employers.

In summary, for researchers, there is a danger that reference to O'Sullivan's (2000) work may become a catch-all explanation that loses sight of complex embedded features in business systems and the impact of these on industrial relations. This points 
to a need for more detailed empiric research on the diffusion of Americanness, particularly the impact of shareholder value as a business driver in the contemporary period. Thus, whilst we suggest that in broadly defined patterns of industrial relations settlement at the level of the firm, more determined short-termism has not led to an explicit lower road; it is necessary to examine in more detail the changes within established patterns of industrial relations management in US MNCs. We intend to report on this in future publications under three broad categories. First, whilst we thus far are reporting on a pattern of pathway adjustment rather than radical change, the pattern of adjustment within a defined settlement could be more significant than the maintenance of a pluralist or welfare capitalist approach. Second, a more detailed interrogation of O'Sullivan (2000) suggests that a more questioning approach to the country-of-origin effect that focuses on internal management debate over the effects of reforming industrial relations settlements will prove fruitful. That is, one that focuses on the absence of innovation in industrial relations management but which nevertheless disentangles the effects of shareholder value and movements to lowerroad approaches as separate issues. Finally, to assess the impact of shareholder value in a more rounded way it will be necessary to examine matched pairs of British firms and US MNCs in the same sector or examine changes in industrial relations management at plants recently acquired by US MNCs. In the absence of these to further substantiate our arguments in this review we will report on the details of pathway adjustment in our cases across the UK, Ireland, Germany and Spain.

\section{Acknowledgements}

This article draws on a body of empiric work undertaken by a large team of researchers led by Anthony Ferner and includes Philip Almond, Ian Clark, Peter Butler, Trevor Colling, Tony Edwards, Len Holden and Michael Muller. The research was funded by an initial grant from Leicester Business School and then the Economic and Social Sciences Research Council and the Anglo-German Foundation for the Study of Industrial Society.

\section{References}

Almond, P., T. Edwards and I. Clark (2003), 'Multinationals and Changing National Business Systems in Europe: Towards the "Shareholder Value Model" ', Industrial Relations Journal, 34, 5, 430-446.

Bach, S. and K. Sisson (2000), 'Personnel Management in Perspective', in S. Bach and K. Sisson (eds), Personnel Management: A Comprehensive Guide to Theory and Practice (Oxford, Blackwell) pp. 1-43.

Barnard, S., S. Deakin and R. Hobbs (2003), " "Fog in the Channel, Continent Isolated": Britain as a Model for EU Social and Economic Policy?', Industrial Relations Journal, 34, 5, 461-476.

Braverman, H. (1974), Labour and Monopoly Capital (New York, Monthly Review Press).

Chandler, A. (1990), Scale and Scope: The Dynamics of Industrial Capitalism (Cambridge, MA, Belknap Press).

Clark, I. (1999), 'Institutional Stability in Management Practice and Industrial Relations: The Influence of the Anglo-American Productivity Council', Business History, 41, 3, 64-92.

Clark, I. (2001), 'Employer Resistance to the Fordist Production Process: "Flawed Fordism" in Post-War Britain', Contemporary British History, 15, 2, 28-53.

(C) Blackwell Publishing Ltd. 2004. 
Clark, I., T. Colling, P. Almond, P. Gunnigle, M. Morley, R. Peters and M. Portillo (2002), 'Multinationals in Europe 2001-2002: Home Country, Host Country and Sector Effects in the Context of Crisis', Industrial Relations Journal, 33, 5, 446-465.

Colling, T. and I. Clark (2002), 'Looking for “Americanness": Home Country, Sector and Firm Effects on Employment Systems in an Engineering Services Company', European Journal of Industrial Relations, 8, 3, 301-324.

Crouch, C. (2003), 'The State, Economic Management and Incomes Policy', in P. Edwards (ed.), Industrial Relations (Oxford, Blackwell) pp. 105-122.

Dessler, G. (2003), Human Resource Management, 9th edn. (Upper Saddle River, NJ, Prentice Hall).

Djelic, M. (1998), Exporting the American Model-The Post-War Transformation of European Business (Oxford, Oxford University Press).

Dunning, J. (1985), 'Multinational Enterprise and Industrial Restructuring in the UK', Lloyds Bank Review, October, 1-19.

Dunning, J. (1996), 'US-Owned Manufacturing Affiliates and the Transfer of Managerial Techniques-The British Case', in M. Kipping and O. Bjarnar (eds), The Americanization of European Business-The Marshall Plan and the Transfer of US Management Models (London, Routledge) pp. 74-91.

Dunning, J. (1998), American Investment in British Manufacturing Industry, Revised and Updated (London, Routledge). First published in 1958.

Edwards, R. (1979), Contested Terrain (New York, Basic).

Edwards, T. and A. Ferner (2002), 'The Renewed American Challenge', Industrial Relations Journal, 33, 2, 94-111.

Ferner, A (1997), 'Country of Origin Effects and Human Resource Management in Multinational Companies', Human Resource Management Journal, 7, 1, 19-37.

Ferner, A., P. Almond, I. Clark, T. Colling, T. Edwards, L. Holden and M. Muller-Camen (2004), 'The Dynamics of Central Control and Subsidiary Autonomy in the Management of Human Resources: Case Study Evidence from US Multinationals in the UK', Organization Studies, 25, 3, 363-393.

Financial Times (2003a), 'Managers Still Rule, Unions Told', 17 January.

Financial Times (2003b), 'Red Tape "Costing Business Up to $£ 6$ Billion Each Year”, 16 June.

Financial Times (2004), 'Productivity on the Rise but the Gap with the US Widens Further', 30 March.

Flanders, A. (1964), The Fawley Productivity Agreements: A Case Study of Management and Collective Bargaining (London, Faber).

Foulkes, F. (1980), Personnel Policies in Large Non-union Companies (Englewood Cliffs, NJ, Prentice Hall).

Hall, P. and D. Soskice (2000), 'An Introduction to the Varieties of Capitalism', in P. Hall and D. Soskice (eds), Varieties of Capitalism-The Institutional Foundations of Comparative Advantage (Oxford, Oxford University Press) pp. 1-77.

Hollingsworth, J. R. (1997), 'The Institutional Embeddedness of American Capitalism', in C. Crouch and W. Streeck (eds), The Political Economy of Modern Capitalism (London, Sage) pp. $133-147$.

Hyman, R. (2003), 'The Historical Evolution of British Industrial Relations', in P. Edwards (ed.), Industrial Relations (Oxford, Blackwell) pp. 37-58.

Jacoby, S. (1997), Modern Manors Welfare Capitalism Since the New Deal (Englewood Cliffs, NJ, Princeton University Press).

Katz, H. and O. Darbishire (2000), Converging Divergencies. Worldwide Changes in Employment Systems (Ithaca, NY, Cornell University Press).

Kipping, M. (1998), “ "Operation Impact”: Converting European Employers to the American Creed', in M. Kipping and O. Bjarnar (eds), The Americanization of European BusinessThe Marshall Plan and the Transfer of US Management Models (London, Routledge) pp. 5573. 
Kochan, T. and P. Osterman (1994), The Mutual Gains Enterprise (Boston, MA, Harvard Business School Press).

Lawler, E. (2002), 'The Folly of Forced Ranking', Strategy and Business, 28, $28-32$.

Muller-Camen, M., P. Almond, P. Gunnigle, J. Quintanilla and A. Tempel (2001), 'Between Home and Host Country: Multinationals and Employment Relations in Europe', Industrial Relations Journal, 32, 5, 435-448.

Nolan, P. and K. O'Donnell (2003), 'Industrial Relations, HRM and Performance' in P. Edwards (ed.), Industrial Relations (Oxford, Blackwell) pp. 489-513.

Nolan, P. and G. Slater (2003), The Labour Market: History, Structure and Prospects', in P. Edwards (ed.), Industrial Relations (Oxford, Blackwell) pp. 58-81.

O'Sullivan, M. (2000), Contests for Corporate Control and Economic Performance in the United States and Germany (Oxford, Oxford University Press).

Thompson, P. (2003), 'Disconnected Capitalism: Or Why Employers Can't Keep Their Side of the Bargain', Work, Employment and Society, 17, 2, 359-378.

UNCTAD (2002), World Investment Report (New York, UN).

Zeitlin, J. and G. Herrigel (eds) (2002), Americanization and Its Limits: Reworking US Technology and Management in Post-War Europe and Japan (Oxford, Oxford University Press). 